\title{
The Effect of Campus Environment towards the Learning Motivation
}

\section{Vinny Stephanie Hidayat ${ }^{1}$, Debbianita ${ }^{2}$, I Nyoman Agus Wijaya ${ }^{3}$, and Sherin Ivana Dewi ${ }^{4}$ \\ Maranatha Christian University \\ vinny.sh@eco.maranatha.edu}

\begin{abstract}
The aim of this research is to determine the effect of Campus Environment (Physical and Non-Physical Environment) towards the learning motivation of students at Maranatha Christian University. The population of this research is the whole of accounting students at Maranatha Christian University. The sample of this research is 91 accounting students at Maranatha Christian University. The method used in this research is explanatory research, and the sampling method used is judgment sampling method. T-test and $F$ test are used for Research hypothesis testing and SPSS version 20.0 is used for multiple regression analysis. The result of this research shows that College Environment affects the student's motivation of studying, thus, the hypothesis of this research is empirically supported.

Keywords: campus environment, motivation of studying, internet Access, physical and non-physical environment
\end{abstract}

JEL $\quad:$ M10

DOI : :10.24002/kinerja.v25i1.3830

Received : 12/23/2021 Reviewed: 02/11/2021 Final Version: 03/09/2021 


\section{INTRODUCTION}

Learning in higher education is influenced by various factors, for example, the teaching staff. This is also influenced by the motivation of the students themselves. Motivation is an internal factor. Self-motivation is very important, such as motivation to attend lectures, motivation to study or graduate on time, and earn a bachelor's degree (Suwastika, 2017).

The campus environment is one of the things that affects student's learning motivation. A conducive campus environment can increase the student motivation. Increasing student motivation to learn would certainly increase their learning achievement in lectures. A conducive campus environment includes good relationships between fellow students, relationships between students and lecturers, and the physical environment such as class size, air temperature in the classroom, noise control, and campus cleanliness (Naibaho, Adi, and Veryco and Sugiarto, 2010).

The success of the learning process through student motivation must be balanced with an adequate campus environment. The university must provide an adequate campus environment and make the atmosphere as comfortable as possible for their students. A good campus environment can support the implementation of learning so that students have an enthusiasm for learning and have an impact on increasing learning achievement. Facilities and infrastructure that are incomplete and deemed inadequate will hinder and disrupt the learning process (Abbas, 2014).

In reality, there are some campuses that cannot provide the conducive environment to support academic activities in whole aspects. For example, the campus that located in crowded area that can disturb student's concentration in studying, or don't have supportive members to develop student's academic achievement (for example, the student does not have good friend or good work team to solve his/her problems or to help him/her in studying).

This research trying to show the importance of good campus environment to support learning motivation, and to encourage the campus to make the supportive environment to increase student's learning motivation.

\section{LITERATURE REVIEW}

\subsection{Motivation to Learn}

According to Mc Donald in Hamalik (2012: 173) motivation is a change of energy in a person's personality which is marked by the emergence of affective and reactions to achieve goals (Anisaturizqi, 2015).

In general, the motivation given can be divided into two (Heidjrachman and Husnan, 2002), such as positive motivation and negative motivation. Positive motivation is the process of affecting people by giving the possibility of getting a 
reward while negative motivation is the process of affecting someone through the power of fear such as losing recognition, money, or position (Dhermawan, Sudibya, and Utama, 2012).

Motivation to learn is a non-intellectual psychological factor. Its unique role is in the development of passion, feeling happy, and excited to learn. Students who have strong motivation will have a lot of energy to carry out learning activities (Sardiman A.M., 2006 in Rahmawati, 2014).

Motivation to learn can arise because of intrinsic factors, in the form of desire and desire to succeed, and encouragement of learning needs, expectations of ideals. While the extrinsic factors are the existence of appreciation, a conducive learning environment, and interesting learning activities. But it must be remembered, both of these factors are caused by certain stimuli, so that someone wants to do learning activities that are more active and enthusiastic (Hamzah Uno B, 2008 in Rahmawati, 2014).

\subsection{Campus Environment}

The campus environment is an environment where students undergo the learning process and carry out activities. The definition of the work environment can provide the same definition of the campus environment. (Naibaho, Adi, Veryco and Sugiarto, 2010).

Sihombing (2004) in Naibaho, Adi, Veryco and Sugiarto (2010) states that: "the work environment is factors outside humans, both physical and non-physical in an organization. Physical factors include work equipment, the temperature at work, crowdedness and density, noise, workspace area, while non-physical factors include work relationships that are formed in the company between superiors and subordinates and among employees.

According to Mangkunegara (2006) in Dhermawan, Sudibya, and Utama (2012), that the work environment includes clear job descriptions, adequate authority, challenging work targets, communication patterns, harmonious work relationships, dynamic work climate, career opportunities, and adequate work facilities. An unsatisfactory work environment can reduce morale and ultimately reduce employee productivity (Ahyari, 1986 in Dhermawan, Sudibya, and Utama, 2012).

\subsection{Physical and Non-Physical Environment}

According to Sihombing (2004: 175), the physical work environment is one of the elements that companies must use so that it can create a sense of security, serenity and can increase good work results to improve employee performance. Furthermore, according to Nitisemito (2000: 184), several factors that affect the physical work environment include color, cleanliness, air circulation, lighting, and security. Meanwhile, according to Setiawan (2008: 83), the factors that affect the formation of a work environment include temperature, humidity, air circulation, 
lighting, noise, mechanical vibration, and safety (Rahmawanti, Swasto, and Prasetya, 2014).

Sedarmayanti (2007) argues that the non-physical environment is all conditions that occur related to work relationships, both with superiors and with colleagues or relationships with subordinates. The same thing happens on campus, such as the relationship between fellow students and between students and lecturers. This nonphysical campus environment is an environmental factor that cannot be ignored (Abas, 2014).

\subsection{Hypothesis Development}

\subsubsection{The Effect of Campus Environment on Student Learning Motivation}

Purwanto (2006: 148) stated that "the learning environment supports and plays a big role in student success". In addition, the results in this research are also in accordance with the research conducted by (Ariwibowo, 2012) with the results of research which stated that there is a positive and significant effect between the learning environments towards learning achievement. A good learning environment is a conducive learning environment. So that if a conducive learning environment can be created, students will be more able to concentrate and their learning goals can be achieved (Noviana, 2014).

The campus environment affects student learning motivation. Research conducted by Naibaho, Adi, Veryco and Sugiarto (2010) stated that respondents give different preferences towards campus environmental variables that affect their learning achievement. Respondents gave the highest score towards the relationship variable between lecturers and students which affected their learning achievement. This good relationship provides them with a safe environment so that they can continue to coordinate with the lecturer on lecture material even though the class is over. The second highest variable is the cleanliness of the campus where with a clean environment, students will be comfortable in the campus environment to have discussions with classmates or do other activities. The lowest variable is internet facilities. Internet facilities are not things that affect their learning achievement. This may be because that students have private internet facilities.

$\mathrm{HO}$ : Campus environment does not affect the learning motivation

$\mathrm{H1}$ : $\quad$ Campus environment affects the learning motivation

\subsection{Research Model}

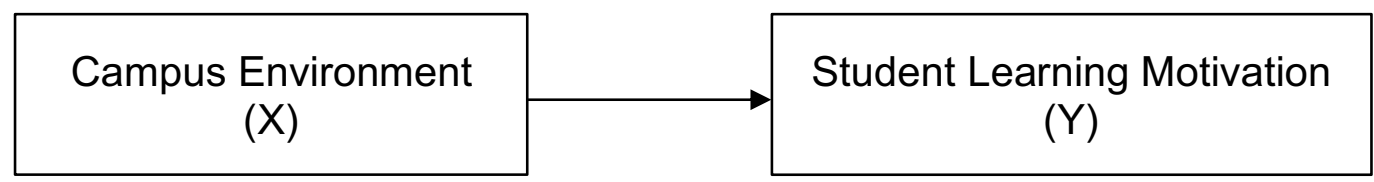

Figure 1. Research Model 


\section{METHODOLOGY}

\subsection{Population and Sampling Techniques}

The sampling technique used in this research is Purposive Sampling, in which the sample was selected with certain considerations (Sugiyono, 2010: 122 in Maharani and Suardana, 2014). The population of this research is all the students of the Accounting Study Program at Maranatha Christian University Bandung.

The sampling criteria for students which will be used in this research are the students of the Faculty of Economics, Accounting Study Program and active student class from 2013-2017.

\subsection{Research Method}

The type of research used in this research is explanatory research. Explanatory research is a research that highlights the relationship between the independent variables (Campus Environment) and the dependent variable (Student's Learning Motivation) and tests the previously formulated hypotheses (Singarimbun and Effendi, 1990: 5, in Arianto, 2013). The research location was conducted at Maranatha Christian University. The researcher conducted a survey (using questionnaries) to analyze the student's perspective about the importance of campus environment to increase their learning motivation.

\subsection{Data Collection Technique}

The technique used to collect data in this research is a questionnaire data collection technique, using a Likert scale of 1-5 and documentation techniques. Questionnaires, which are data collection by using a written list of questions that are used to obtain information from respondents in the sense of reports about personalities or things they know (Arikunto, 1993 in Rizqi, 2017). Documentation, a large number of facts and data stored in the form of documentation. Most of the available data is in the form of letters, notes, reports, artifacts, and photos (Noor, 2011 in Rizqi, 2017).

\subsection{Data Analysis Technique}

Ghozali (2009) in Wahyuni (2014) stated that the validity test is used to measure the validity of a questionnaire. A questionnaire is said to be valid if the questions on the questionnaire are able to reveal something that will be measured by the questionnaire. To test this validity, It will require the use of the SPSS program. The testing technique that is often used by researchers to test the validity is to use the Pearson Bivariate correlation (Pearson Moment Product). This analysis is done by correlating the score of each item with the total score. The total score is the sum of all items. Question items that are significantly correlated with the total score indicate that these items are able to provide support in revealing what they want to reveal à Valid. If $r$ count $\geq r$ table (2-sided test with sig. 0.05) then the instrument or question items have a significant correlation towards the total score (declared valid). 
The measurement of reliability in this research was carried out using the Cronbach Alpha coefficient. There is a valuable provision for measuring reliability with the Cronbach Alpha $(\alpha)$ statistical test. A construct is said to be reliable if it has a Cronbach Alpha> 0.6. (Nunnally, 1994 in Gunawan, Meyliana and Natalia, 2019). This Study using this Classic Assumption Test: Normality Test and Heteroscedasticity Test. This Study using Partially Significant Test (T-test) and Simple Regression Test.

Table 1. Operationalization of Variables

\begin{tabular}{|c|c|c|c|}
\hline No & Variable & Indicator & Scale \\
\hline 1 & & Class Size & Likert \\
\hline 2 & & Class Layout & Likert \\
\hline 3 & Campus & Campus Cleanliness & Likert \\
\hline 4 & environment & Library Facilities & Likert \\
\hline 5 & (Physical and & Classroom Air Temperature & Likert \\
\hline 6 & non-rnysical) & Noise Level & Likert \\
\hline 7 & & Relationship Between Students & Likert \\
\hline 8 & & $\begin{array}{l}\text { Relationship Between Lecturers and } \\
\text { Students }\end{array}$ & Likert \\
\hline 9 & & Task Completion Attitude & Likert \\
\hline 10 & & Punctuality & Likert \\
\hline 11 & Tiotivation to & Drive for Achievement & Likert \\
\hline 12 & Learn & Competitive Spirit & Likert \\
\hline 13 & & Attitudes in Receiving Lecture Materials & Likert \\
\hline 14 & & $\begin{array}{l}\text { Activeness in Teaching and Learning } \\
\text { Activities }\end{array}$ & Likert \\
\hline
\end{tabular}

\section{RESULT AND DISCUSSION}

The object of this research consists of active students of the Faculty of Economics, Maranatha University Bandung Accounting Study Program class of 2013-2017. 
Table 2. Validity Test Results

\begin{tabular}{|c|c|c|c|}
\hline No & $\mathbf{r}_{\mathbf{x y}}$ & rtabel & Description \\
\hline 1 & 1.000 & 0.2061 & Valid \\
\hline 2 & 0.288 & 0.2061 & Valid \\
\hline 3 & 0.358 & 0.2061 & Valid \\
\hline 4 & 0.246 & 0.2061 & Valid \\
\hline 5 & 0.269 & 0.2061 & Valid \\
\hline 6 & 0.283 & 0.2061 & Valid \\
\hline 7 & 0.250 & 0.2061 & Valid \\
\hline 8 & 0.346 & 0.2061 & Valid \\
\hline 9 & 0.253 & 0.2061 & Valid \\
\hline 10 & 0.215 & 0.2061 & Valid \\
\hline 11 & 0.301 & 0.2061 & Valid \\
\hline 12 & 0.333 & 0.2061 & Valid \\
\hline 13 & 0.264 & 0.2061 & Valid \\
\hline 14 & 0.214 & 0.2061 & Valid \\
\hline
\end{tabular}

From the table above, it can be seen that all $r$ count $>r$ table, so the questionnaire is declared valid. The variable will be said to be reliable if the result (Cronbach's alpha) is $>0.60$. Therefore, this research variable is declared reliable because it has a Cronbach's alpha of 0.813 .

Interpretation of the test results, the data has a normal distribution, because all variables have a sig value above 0.05 , where the sig value is 0.321 . Based on the Scatterplots (in appendix), it is known that:

1. The scatter data points are above or around the 0

2. The points don't converge, just above or below it

3. The spread of data points does not form a wavy pattern that widens then narrows and widened again

4. The distribution of data points is not patterned

Table 4. T-Test Result

\begin{tabular}{|c|c|c|}
\hline \multicolumn{3}{|c|}{ Collinearity Statistics } \\
\hline Model & $\mathbf{t}$ & $\mathbf{s i g}$ \\
\hline $\begin{array}{c}\text { (Constant) } \\
\text { Campus } \\
\text { Environment }\end{array}$ & 5,435 & .000 \\
\hline
\end{tabular}

Based on the results of calculations using SPSS, the t value is 4,728 , with a sig value of 0,000 , where the sig value is less than 0.05 . So, it can be concluded that the Campus Environment's independent variable partially has a significant positive effect towards the dependent variable (Learning Motivation). From the partial test results, the following result is obtained $\mathrm{H} 1$ : Campus environment affects the learning 
motivation of the Accounting Study Program Students of Maranatha Christian University, Bandung is accepted.

Table 5. Simple Linear Regression Results

\begin{tabular}{|c|c|c|c|c|c|c|c|c|}
\hline \multicolumn{9}{|c|}{ Coefficients $^{\mathrm{a}}$} \\
\hline \multirow{2}{*}{\multicolumn{2}{|c|}{ Model }} & \multicolumn{2}{|c|}{ Unstandardized Coefficients } & \multirow{2}{*}{$\begin{array}{c}\text { Standardized } \\
\text { Coefficients }\end{array}$} & \multirow[t]{2}{*}{$t$} & \multirow[t]{2}{*}{ Sig. } & \multicolumn{2}{|c|}{ Collinearity Statistics } \\
\hline & & $B$ & Std. Error & & & & Tolerance & VIF \\
\hline \multirow{2}{*}{1} & (Constant) & 16,074 & 2,958 & & 5,435 &, 000 & & \\
\hline & LINGKAMPUS &, 732 &, 155 &, 448 & 4,728 &, 000 & 1,000 & 1,000 \\
\hline
\end{tabular}

a. Dependent Variable:MOTIVASI BELAJAR

$$
\begin{gathered}
Y=a+b x \\
Y=16,074+0,732
\end{gathered}
$$

Description:

$\mathrm{Y} \quad=$ Motivation to Learning variable

$\mathrm{X} \quad=$ Campus Environment variable

$\mathrm{a} \quad=$ constant (if the value of $\mathrm{x}$ is 0 , then $\mathrm{Y}$ will be equal to $\mathrm{a} /$ constant

$\mathrm{b} \quad=$ regression coefficient (value of increase or decrease)

a = constant of 16,074 , meaning that if you use the internet $(X)$ the value is 0 , then the output value $(\mathrm{Y})$ is 16.074

b = regression coefficient of 0.732 , meaning that if the campus environment has increased by 1 , the output result $(Y)$ has increased equal to 0.768

The campus environment affects student learning motivation. This environment includes both physical and non-physical environments. A comfortable physical environment (such as security, class layout, campus facilities, etc.) also affects the comfort of students in their activities, both teaching and learning activities in class and other activities outside the classroom, such as activities of the Student Association or other Student Activity Units. Of course, student comfort will have an impact on increasing student motivation in learning. For example, students will be more concentrated and motivated in learning, if students feel that their campus is a safe place. We can imagine that if students are overshadowed by feelings of fear of the fate of their safety, of course, their motivation to learn will also dissipate. Another example, if students feel that the class is clean, has good air circulation and lighting, and does not smell bad, of course, the students will concentrate more and be enthusiastic in digesting the material provided by the lecturer. The non-physical environment is also very supportive of student learning motivation. A good relationship with their peers will certainly increase the enthusiasm of students in learning, for example, they are more comfortable doing group assignments and communicating about the course material they get, so that if students do not understand course material, they can get enlightenment or help from their partner. A good relationship between lecturers and students has a very significant effect towards student learning motivation. If students feel comfortable with their lecturers, they will not hesitate to ask questions and share about the course material they get, 
so they don't feel stressed if they can't understand the material/course assignments given by the lecturer.

This is in accordance with the research conducted by Naibaho, Adi, and Veryco and Sugiarto (2010) which stated that respondents give different preferences to campus environmental variables that affect their learning achievement. Respondents gave the highest score on the relationship variable between lecturers and students that had an influence towards their learning achievement. This good relationship provides them with a safe environment so that they can continue to coordinate with the lecturer towards lecture material even though the class is over. The second highest variable is the cleanliness of the campus where with a clean environment, students will be comfortable in the campus environment to have discussions with classmates or do other activities. The lowest variable is internet facilities. Internet facilities are not things that have an influence on their learning achievement. This may be due to the fact that students have private internet facilities.

\section{CONCLUSION}

Campus environment affects the Learning Motivation. Universities can continuously improve the campus environment, so that the comfort of students in their activities will increase. The comfort and safety of students in the teaching and learning process and other activities on campus, of course, it will increase student motivation and academic achievement.

\section{REFERENCE}

Abas, F, 2014. Pengaruh Lingkungan Kampus Terhadap Motivasi Belajar Pada SEMA, HIMA, dan Unit Kegiatan Mahasiswa Universitas Kristen Maranatha. Skripsi, Bandung: Jurusan Manajemen Fakultas Ekonomi Universitas Kristen Maranatha.

Anisaturizqi, I, 2015. Pengaruh Keterampilan Mengajar Dosen Dan Lingkungan Kampus Terhadap Motivasi Belajar Mahasiswa Pendidikan Akuntansi Universitas Negeri Semarang Angkatan 2013. Skripsi, Semarang: Jurusan Pendidikan Ekonomi Fakultas Ekonomi Universitas Negeri Semarang.

Arianto, D.A.N, 2013. Pengaruh Kedisiplinan, Lingkungan Kerja dan Budaya Kerja Terhadap Kinerja Tenaga Pengajar. Jurnal Economia. 9(2),191-200.

Dhermawan, A.A.N.B., Sudibya, I.G.A., and Utama, I.W.M., 2012. Pengaruh Motivasi, Lingkungan Kerja, Kompetensi dan Kompensasi Terhadap Kepuasan Kerja Dan Kinerja Pegawai Di Lingkungan Kantor Dinas Pekerjaan Umum Provinsi Bali. Jurnal Manajemen, Strategi Bisnis, Dan Kewirausahaan. 6(2), 173-184. 
Gunawan, Y., Meyliana and Natalia, M., 2019. Pengaruh Kualitas Pelayanan Account Representative (AR) dan Tax Knowledge Terhadap Kepatuhan Wajib Pajak (Studi Pada Wilayah KPP Madya Bandung). Jurnal Akuntansi Maranatha. 11(1), 176-186.

Maharani, I.G.A.C., and Suardana, K.A., 2014. Pengaruh Corporate Governance, Profitabilitas dan Karakteristik Eksekutif Pada Tax Avoidance Perusahaan Manufaktur. E-Jurnal Akuntansi Universitas Udayana, 9(2), 525-539.

Naibaho, H., Adi, F., Veryco, and Sugiarto. 2010. Pengaruh Lingkungan Kampus Terhadap Motivasi Belajar Mahasiswa (Studi Kasus Universitas Pelita Harapan Surabaya). Jurnal Manajemen Pemasaran. 5(1), 22-26.

Noviana. 2014. Pengaruh Fasilitas Belajar dan Lingkungan Belajar Terhadap Motivasi Belajar Siswa Program Keahlian APK di SMK Taruna Jaya Gresik. Jurnal Administrasi Perkantoran (JPAP). 2(2), 1-16.

Rahmawati, E. 2014. Pengaruh Lingkungan Sekolah Terhadap Motivasi Belajar Siswa Kelas VIII SMP Muhammadiyah 22 Pamulang. Skripsi, Jakarta: Jurusan Pendidikan Agama Islam Fakultas IImu Tarbiyah dan Keguruan Universitas Islam Negeri Syarif Hidayatullah.

Rahmawanti, N.P., Swasto, B., and Prasetya, A. 2014. Pengaruh Lingkungan Kerja Terhadap Kinerja Karyawan (Studi Pada Karyawan Kantor Pelayanan Pajak Pratama Malang Urata. Jurnal Administrasi Bisnis (JAB). 8(2), 1-9.

Rizqi, W.A. 2017. Pengaruh Lingkungan Pendidikan Terhadap Motivasi Belajar Siswa Kelas X Di MA NU Banat Kudus Tahun Pelajaran 2016/2017. Skripsi, Semarang: Fakultas IImu Tarbiyah dan Keguruan, Ilmu Pendidikan Agama Islam Universitas Islam Negeri Walisongo.

Suwastika, I.W.K., 2017. Pengaruh Lingkungan Terhadap Motivasi Belajar Mahasiswa STIKOM Bali. Jurnal IImiah Manajemen \& Akuntansi. 23(2), 75-88.

Wahyumi, N., 2014. Uji Validitas dan Reliabilitas. BINUS University Quality Management Center. [online] http://amc.binus.ac.id/2014/11/01/u-j-i-v-a-l-i-d-i-t-a-sd-a-n-u-j-i-r-e-l-i-a-b-i-l-i-t-a-s/[Accessed from 22/05/2019] 


\section{Appendix}

Normality Test Results

\section{One-Sample Kolmogorov-Smirnov Test}

\begin{tabular}{|lc|r|}
\hline & & $\begin{array}{c}\text { Unstandardized } \\
\text { Residual }\end{array}$ \\
\hline $\mathrm{N}$ & Mean & 91 \\
Normal Parametersa, & Std. & $0 \mathrm{E}-7$ \\
& Deviation & 3,73818100 \\
Most Extreme & Absolute &, 100 \\
Differences & Positive &, 069 \\
Kolmogorov-Smirnov Z & Negative &,- 100 \\
Asymp. Sig. (2-tailed) & &, 955 \\
\hline
\end{tabular}

a. Test distribution is Normal.

b. Calculated from data.

Plot of Heteroscedasticity Test Results

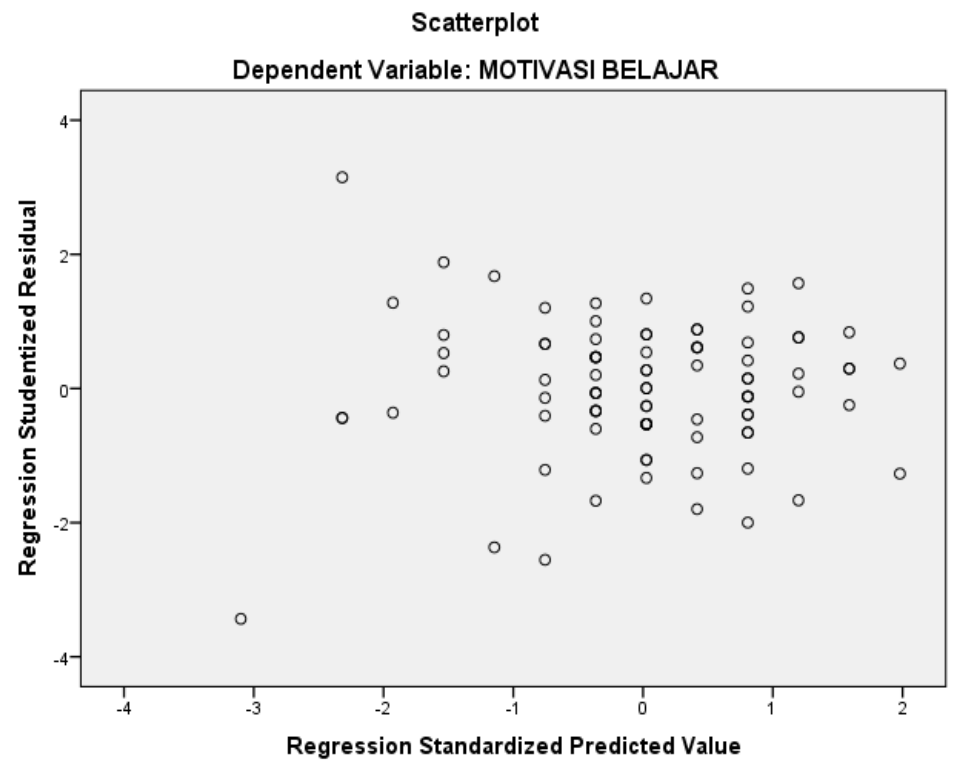

